\title{
Note on a statue of thutmosis III of the Egyptian museum of Florence
}

\section{Literature review}

In the Egyptian Museum in Florence there is a statue dedicated to Pharaoh Thutmosis III; in 1999 Prof. Silvio Curto asked me for a note for his work. Since then his plans changed, he wrote me a delicate letter (Figure 1) in which he complimented my text, but he told me he would not use it and incited me to publish it elsewhere. So I take this opportunity to present the note, which I dedicate to the memory of Silvio Curto.

The statue arrived in Florence among the material brought by Ippolito Rosellini in consequence of the famous Franco-Tuscan expedition, which had been conducted in Egypt together with Jean François Champollion in 1828 and $1829 .{ }^{1}$ A statue corresponding to the description of the Florentine one had been seen and described in the place of Kalabsha by several travelers in the early nineteenth century, ${ }^{2}$ and Silvio Curto identified it with the statue brought by Rosellini to Florence. ${ }^{3}$ In the first volume of the publication "I monumenti dell'Egitto e della Nubia. Monumenti Storici" Rosellini writes: "In Nubia trovammo una statua seduta di granito grigio e poco men grande del vero, la quale porta il nome di Moeris e del paese ove la trovammo. Ma sfortunatamente è mancante della testa: pur nonostante è notabile per la circostanza locale che dimostra, Moeris aver avuto dominio anche in Nubia. Feci trasportar questa statua, ed or si conserva nel R. Museo di Firenze". ${ }^{4}$ So Rosellini says that the statue comes from Nubia, without specifying, however, that it was taken from Kalabsha, while in 1930, in the presentation of the material brought from Egypt, he had not written anything about his origin..$^{5}$ In reality the statue was then erroneously described as found in Thebes, both by Arcangelo Michele Migliarini in $1859,{ }^{6}$ and by Ernesto Schiaparelli in 1887 in his catalog of the material of the Egyptian Museum in Florence. ${ }^{7}$

The statue, with the inventory number 1789, represents the pharaoh seated on a cube-shaped throne (Figure 2); is in black granite and the measures are h. cm. 114.5, base cm. $74 x 40$. The throne has a small back elevated and a dorsal pillar. The head is lost and only the lower part of the ritual beard remains; the king wears a short cloak that covers the body surrounding his shoulders, up to his knees, with the arms crossed over his chest. In his hands, which come out of the cloak, he holds the scepter heka and the nekhekh flagellum, emblems of royal power; between the legs there is an animal tail in relief, while under the feet nine bows are engraved, symbol of the war victories of the

${ }^{1}$ On the expedition see the exhibition catalogue M. Betrò (ed.), Lungo il Nilo. Ippolito Rosellini e la spedizione franco-toscana in Egitto 1828-1829, Firenze 2010

${ }^{2} \mathrm{PM}$ VII, 20

${ }^{3}$ S Curto, V Maragioglio, C Rinaldi, L Bongrani, Kalabsha, Roma 1965, 82

${ }^{4}$ I. Rosellini, I monumenti dell'Egitto e della Nubia, Monumenti Storici, I, Pisa 1832, 233-234 note 2

${ }^{5}$ I. Rosellini, Breve notizia degli oggetti di antichità egiziane riportati dalla Spedizione toscana in Egitto e in Nubia, Firenze 1830, 93 n.104

${ }^{6}$ MA Migliarini, Indication succinte des monuments Egyptiens du Musée de Florence, Firenze 1859, 45 ff. n.1789

${ }^{7}$ E. Schiaparelli, Museo Archeologico di Firenze - Antichità egizie, Roma 1887,195 n. 1503

\author{
Volume 3 Issue 2 - 2018
}

M Cristina Guidotti

Director of the Egyptian Museum of Florence, University of Pisa, Egypt

\begin{abstract}
Correspondence: M Cristina Guidotti, Director of the Egyptian Museum of Florence, University of Pisa, Egypt, Email mariacristina.guidotti@beniculturali.it
\end{abstract}

Received: March 19, 2018| Published: April II, 2018

pharaoh. The dress worn by Thutmosis is characteristic of the festival Sed (Heb-Sed), which was celebrated after thirty years of reign to renew the strength of the pharaoh, reaffirming its sovereignty and its ability to govern the country. Echo of ancient prehistoric rites, the jubilee festival consisted of a series of ceremonies in which the king also wore this particular short cloak. This iconography is rather rare in the royal statuary. The examples that can be cited as comparison are of a period prior to the reign of Thutmosis III: among these are the statues of the Pharaohs Pepi I of the VI dynasty, Montuhotep of the XI dynasty and Sobekhotep of the Second Intermediate Period, ${ }^{8}$ all wearing the short cloak characteristic of the celebration of the Sed festival.

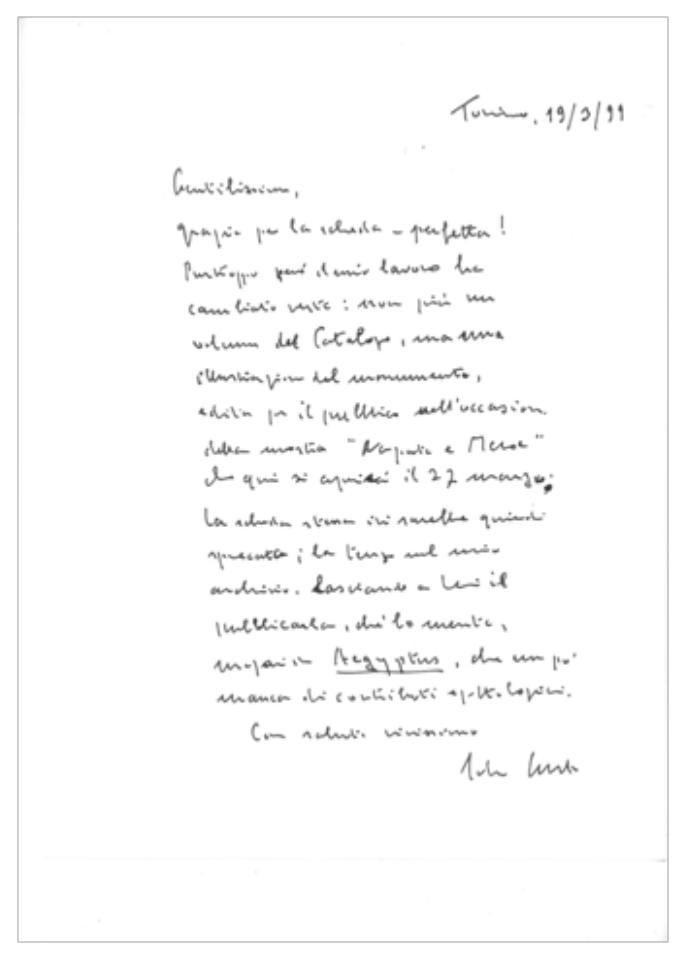

Figure I Delicate letter from Prof. Silvio Curto.

${ }^{8}$ J. Vandier, Manuel d'archéologie égyptienne, III, La statuaire, Paris 1958, 37, 164 and 217, tavv. VIII, 1 LVI, 1 and LXXII, 1 


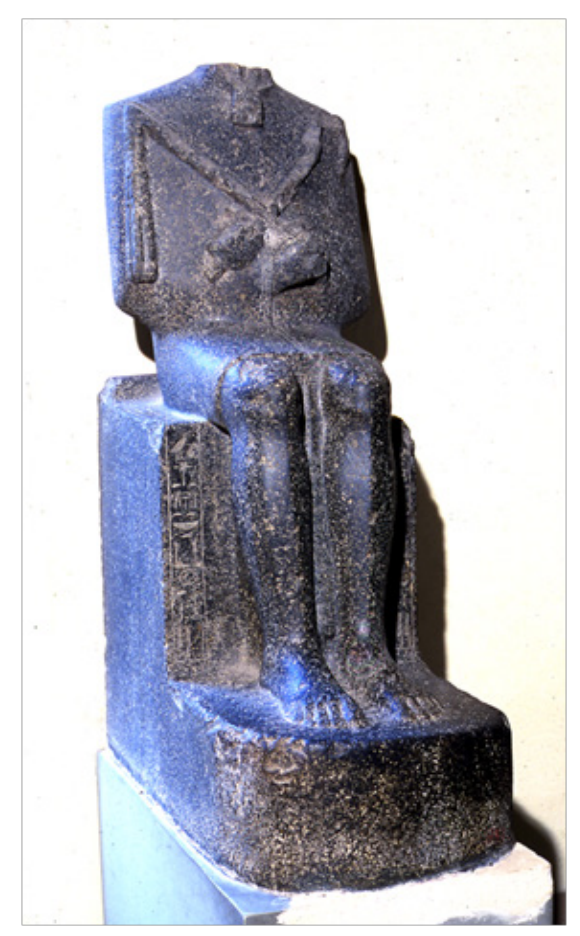

Figure 2 The pharaoh seated on a cube-shaped throne.
The throne on which is seated the pharaoh rest on a parallelepipedshaped base, with a rounded front side. On the dorsal pillar there is a vertical inscription with the name and first name of Thutmosis III, accompanied by the usual titles. We read: "The king of Upper and Lower Egypt, lord of doing things Menkheperra, son of Ra Thutmosis, living forever". The two inscriptions that flank the statue, running on the throne, still have the names of the pharaoh accompanied by other titles. On one side we read: "The good god, lord of the two lands, lord of doing things Menkheperra, beloved by Khnum and by Satis, lady of South Elephantine". On the other side we read: "Son of Ra, of his flesh, who loves him Thutmosis, beloved by Sopdu and Neith, lady of South Elephantine". The place of South Elephantine is to be identified with Semna, located between the Lower Nubia and the Upper Nubia ${ }^{9}$ and this confirms the Nubian provenance of the statue. It is also probable, as affirm Silvio Curto $^{10}$, that the statue was transported already in ancient times, perhaps by the Ptolemies or by the Romans, from Semna to Kalabsha, where it was seen in the early nineteenth century and from where it was taken from Rosellini.

\section{Acknowledgement}

None.

\section{Conflict of interest}

Author declares that there is no conflict of interest.

\footnotetext{
${ }^{9}$ Curto 1965,84

${ }^{10}$ Curto 1965,84
} 